\title{
Comparison of Three Different Fertigation Strategies for Drip Irrigated Table Grapes - Part III. Growth, Yield and Quality
}

\author{
C.L. Howell*, P.A Myburgh and W.J. Conradie \\ ARC Infruitec-Nietvoorbij ${ }^{1}$, Private Bag X5026, 7599, Stellenbosch, South Africa
}

Submitted for publication: April 2012

Accepted for publication: September 2012

Key words: Dan-ben-Hannah, daily pulses, berry crack, crop load, export

\begin{abstract}
A field trial was carried out in a drip irrigated Dan-ben-Hannah/Ramsey vineyard near Paarl in the Berg River Valley region of South Africa to compare three fertigation strategies. Fertilisers were applied (i) two weeks after bud break, fruit set and post-harvest (LF), (ii) weekly from two weeks after bud break until ten weeks after harvest, except during berry ripening (WF), and (iii) in daily irrigation pulses (DF). Grapevines of all treatments received c. $116 \mathrm{~kg} / \mathrm{ha} \mathrm{N}, 22 \mathrm{~kg} / \mathrm{ha} P$ and $92 \mathrm{~kg} / \mathrm{ha} \mathrm{K}$ per season. Grapevines of all the fertigation strategies were thinned to obtain a normal and high crop load, which is 26 and 36 bunches per grapevine respectively for Dan-ben-Hannah. Crop load did not affect vegetative growth, berry size or bunch mass. However, compared to LF and WF, DF increased the berry size of grapevines bearing 26 bunches. Crop load tended to reduce juice TSS, irrespective of fertigation strategy, particularly in 2002/03. Neither fertigation strategy nor crop load affected TTA and pH. Less berry crack contributed to a higher yield and higher export percentage of the DF grapes. In addition, bigger berries, and therefore better appearance, also contributed to the higher export quality of the DF grapes. Although the DF grapevines bearing 36 bunches produced grapes of poorer colour and overall impression, they were within export norms. Based on the foregoing, the DF strategy should not be regarded as the ultimate solution for table grape production. However, it can be recommended for vineyards on poor soils or where berry crack occurs commonly.
\end{abstract}

\section{INTRODUCTION}

The objective of table grape growers in South Africa is to produce high yields of export quality fruit. Since the growth, yield and quality of table grapes depend on water and nutrients, careful management of irrigation and fertilisation is essential (Keller, 2005). The application of fertilisers through irrigation water is a common strategy to supply the water and nutrient requirements of grapevines (Saayman \& Lambrechts, 1995a; Conradie \& Myburgh, 2000; Myburgh, 2012). Increasing $\mathrm{N}$ levels improved grapevine vegetative growth and yield, but decreased the berry mass of fertigated Barlinka grapevines in a sandy soil in the Hex River Valley (Saayman \& Lambrechts, 1995b). However, N level did not affect the number of export quality bunches. It was found that $67 \%$ of the $\mathrm{N}$ requirement applied from bud break to véraison, and the remaining 33\% four weeks after harvest, increased shoot growth and bunch size (Saayman \& Lambrechts, 1995b). In a more recent study, the vegetative growth and yield of Bukettraube grapevine growing in the Lower Olifants River region were shown not to be affected by fertigation when compared to conventional fertilisation, i.e. granules broadcast manually (Conradie \& Myburgh, 2000). When fertigated grapevines in a sandy soil received $80 \mathrm{~kg} / \mathrm{ha} \mathrm{N}$ and $60 \mathrm{~kg} / \mathrm{ha} \mathrm{K}$, cane mass was reduced compared to grapevines fertigated with $120 \mathrm{~kg} / \mathrm{ha} \mathrm{N}$ and $80 \mathrm{~kg} / \mathrm{ha}$ K (Conradie \& Myburgh, 2000). Reynolds et al. (2005) reported that fertigation of $\mathrm{N}$, either as a single application, two applications or weekly applications from bud burst to véraison, did not influence vegetative growth, yield or berry mass of Concord grapevines.

Total soluble solids (TSS), total titratable acidity (TTA) and $\mathrm{pH}$ in the juice of Bukettraube grapes in the Lower Olifants River region were not improved by fertigation compared to conventional fertilisation (Conradie \& Myburgh, 2000). Reynolds et al. (2005) reported that fertigation with $\mathrm{N}$, either as a single application, two applications or weekly applications from bud burst to véraison did not influence TSS in Concord grapes. Two N fertigation applications increased TTA in comparison to single or weekly applications. Furthermore, the juice $\mathrm{pH}$ of grapes that were fertigated with a single application was lower compared to that of grapes fertigated with two or more

\footnotetext{
${ }^{1}$ The Fruit, Vine and Wine Institute of the Agricultural Research Council
}

*Corresponding author: E-mail: howellc@arc.agric.za

Aknowledgements: The authors wish to thank the ARC, for infrastructure and other resources, the Deciduous Fruit Producers' Trust (DFPT) for partial funding, the Soil and Water Science staff at the ARC Infruitec-Nietvoorbij for technical support and Mr A. Hoekstra for permission to work in his vineyard 
applications. When Niagara grapevines were fertigated with urea from bud break to véraison, there was no differences in grapevine response compared to grapevines fertigated with the same amount of nutrients applied in weekly increments from flowering to véraison (Reynolds et al., 2005). More export quality bunches were packed when grapevines bore 15 bunches per grapevine compared to crop loads of 22 bunches per grapevine or higher (Saayman \& Lambrechts, 1995b). The superior colour of the berries produced on low crop load grapevines probably contributed to the better export quality. However, higher crop loads reduced bunch mass and TSS, but had no effect on berry mass.

Previous studies on table grapes have shown that vegetative growth, yield and grape quality can all be related to the grapevine water status (Van Rooyen et al., 1980; Myburgh, 1996, 2003; El-Ansary et al., 2005; Myburgh \& Howell, 2007a, 2007b; Myburgh, 2012). Fertigation frequencies vary from daily applications to longer intervals. Since a number of irrigation pulses per day can reduce grapevine water constraints to a minimum, irrespective of crop loads, which were either 26 or 36 bunches per grapevine (Myburgh \& Howell, 2012), it may be possible to increase yield by using such a strategy. Currently there are no guidelines for the application of nutrients by means of a number of pulses during the day to supply the grapevine's daily requirements on a continuous basis throughout the season. The objective of this study therefore was to compare the effects of different fertigation strategies on vegetative growth, yield and fruit quality of table grapevines.

\section{MATERIALS AND METHODS}

\section{Design and layout of experiment}

This project was carried out in a commercial, drip irrigated Dan-ben-Hannah/Ramsey vineyard near Paarl in the Berg River Valley region of South Africa during the 2001/02, 2002/03 and 2003/04 seasons. The region has a Mediterranean climate and, based on growing degree days from September until March (Winkler, 1962), is in a class V climatic region (Le Roux, 1974). Dan-ben-Hannah, also known as Black Emperor, originated in Israel where it was selected from a cross between Black Mikveh and Alphonse Lavallee (Hurndall, 2005). Details of the soil, irrigation system and viticultural practices have been described by
Myburgh and Howell (2012). A factorial experiment layout, with three fertigation treatments and two crop load levels, was used (Table 1), and treatments were replicated six times. Each experiment plot consisted of a row of sixteen experiment grapevines, with two border grapevines at each end and a border row on each side to minimise overlap of treatment effects. In each plot, bunches on eight experiment grapevines were thinned to obtain a normal crop load $(\mathrm{N})$, which is 26 bunches per grapevine for Dan-ben-Hannah under the given conditions. The remaining grapevines were thinned less severely to bear a relatively high crop load $(\mathrm{H})$ of 36 bunches per grapevine.

Treatments were applied from two weeks after bud break in September until the end of March, when the first autumn rains occurred. The grapevines fertigated at a low frequency (LF) received fertiliser two weeks after bud break, at fruit set and again after harvest. Weekly fertigated (WF) grapevines received the same total amount of fertiliser as the LF grapevines, but it was applied weekly for six weeks from two weeks after bud break to flowering, weekly for six weeks from fruit set to véraison, and weekly for ten weeks after harvest. The third strategy entailed daily pulse fertigation (DF) according to the daily requirements of the grapevines during the various phenological stages (Conradie, 1980, 1981).

\section{Vegetative growth and yield components}

Cane mass was measured at pruning during winter (July), in each plot, using a hanging balance. Berry mass and volume were determined at harvest. To ensure that berry sampling was unbiased and representative, bunches were selected using an elastic cord that was marked at ten fixed intervals. This cord was stretched along the bunch zone across all the experiment grapevines in each plot. Five berries were picked from each of the ten bunches closest to the markers on the cord. This procedure was repeated on both sides of the vine row to obtain a sample of 100 berries. To measure bunch mass and estimate yield, 20 bunches were selected for evaluation at each experiment plot using the elastic cord method. These bunches were picked and their mass was determined. Yield per plot was estimated by multiplying mean bunch mass by number of bunches. Mean yield per plot was converted to tons per hectare.

TABLE 1

Fertigation and crop load treatments applied during the 2002/03 and 2003/04 seasons.

\begin{tabular}{llll}
\hline Treatment $^{(1)}$ & Crop load $^{(2)}$ & Fertigation strategy & Irrigation frequency \\
\hline $\mathrm{LF}_{\mathrm{N}}$ & Normal & 3 times/season & weekly \\
$\mathrm{WF}_{\mathrm{N}}$ & Normal & weekly $^{(4)}$ & weekly \\
$\mathrm{DF}_{\mathrm{N}}$ & Normal & daily pulses & $(5)$ \\
$\mathrm{LF}_{\mathrm{H}}$ & High & 3 times $/$ season $^{(3)}$ & daily pulses \\
$\mathrm{WF}_{\mathrm{H}}$ & High & weekly & weekly \\
$\mathrm{DF}_{\mathrm{H}}$ & High & daily pulses & weekly \\
\hline
\end{tabular}

${ }^{(1)} \mathrm{LF}=$ Low frequency, $\mathrm{WF}=$ Weekly fertigation, $\mathrm{DF}=$ Daily pulse fertigation. ${ }^{(2)} \mathrm{N}=$ Normal, i.e. 26 bunches per grapevine, $\mathrm{H}=$ High, i.e. 36 bunches per grapevine. ${ }^{(3)}$ Two weeks after bud break, fruit set and post-harvest. ${ }^{(4)}$ Same amount of fertiliser as LF, but applied weekly for six weeks from two weeks after bud break, weekly for six weeks from fruit set to véraison, and weekly for ten weeks post-harvest. ${ }^{(5)}$ Refer to Myburgh and Howell (2012). 


\section{Grape quality}

Juice TSS, TTA and $\mathrm{pH}$ were determined at the ARC InfruitecNietvoorbij according to standard winery procedures. The 20 harvested bunches were classified in the packshed according to their suitability for export or local retail. Bunches that did not conform to either of these standards were rejected and used for juice production. The number of $5 \mathrm{~kg}$ export boxes per hectare for each treatment was calculated from the export percentage and the yield. The storage capability of the grapes was evaluated by Hortec Research Services at Stellenbosch, after standard cold storage for four weeks at $4^{\circ} \mathrm{C}$ followed by one week at $10^{\circ} \mathrm{C}$. Thereafter, a panel of at least fifteen members evaluated the grapes sensorially during all seasons for colour, firmness, taste and overall impression according to a cardinal scale, as either poor, fairly poor, average, fairly good and good. In the 2002/03 season, berry crack occurred in the vineyard following $61 \mathrm{~mm}$ rainfall on 21 December, which resulted in severe Botrytis cinerea infection. Early in January 2003, the occurrence of berry crack was quantified by selecting 20 bunches in each experiment plot using the elastic cord method as described above. The number of bunches infected, as well as the number of infected berries per bunch, were counted. The physical strength of the berry skins was quantified as follows. A piece of berry skin, c. 15 $\mathrm{mm}$ in diameter, was clamped between two metal washers in a pressure chamber commonly used to measure leaf water potential. Pressure was allowed to increase at a rate of 25 $\mathrm{kPa}$ per second (Myburgh, 2010), and the pressure at which the berry skin burst was recorded.

\section{Statistical analysis}

Since the treatment application began late in the 2001/02 season, it was regarded as a pilot year. Data from the 2002/03 and 2003/04 seasons are presented in this article. Frequencies observed in the five sensorial quality classes were subjected to a general linear model (GLM) technique with a logistic link function. Maximum likelihood estimators (Xbetas) were calculated on an underlying scale (McCullagh \& Nelder, 1989). Two-way analyses of variance were performed on the mean degree of grape colour, firmness, taste and overall impression data using SAS version 8.2 (SAS, 1999). The Shapiro-Wilk test was used to test for non-normality (Shapiro \& Wilk, 1965). Student's t least significant difference (LSD) values were calculated to facilitate comparison between treatment means. Means that differed at $\mathrm{p} \leq 0.05$ were considered to be significantly different.

\section{RESULTS AND DISCUSSION \\ Vegetative growth}

In 2002/03, DF increased cane mass compared with WF, irrespective of crop load (Fig. 1). The vegetative growth of the $\mathrm{LF}_{\mathrm{N}}$ grapevines was also stronger than that of the WF grapevines. A similar trend was observed in 2003/04. Since LF and WF received the same irrigation volumes and did not experience any water constraints (Myburgh \& Howell, 2012), the vegetative growth differences were most probably caused by differences in nutrient uptake efficiencies. The lower vegetative growth could have been caused by less efficient $\mathrm{N}$ uptake, as reflected in lower petiole $\mathrm{N}$ of the WF grapevines compared to the LF and DF grapevines (Howell \& Conradie, 2013). In contrast, $\mathrm{N}$ fertigation, either as a single application, two or weekly applications from bud burst to véraison did not influence the vegetative growth of Concord grapevines (Reynolds et al., 2005). Vegetative growth was

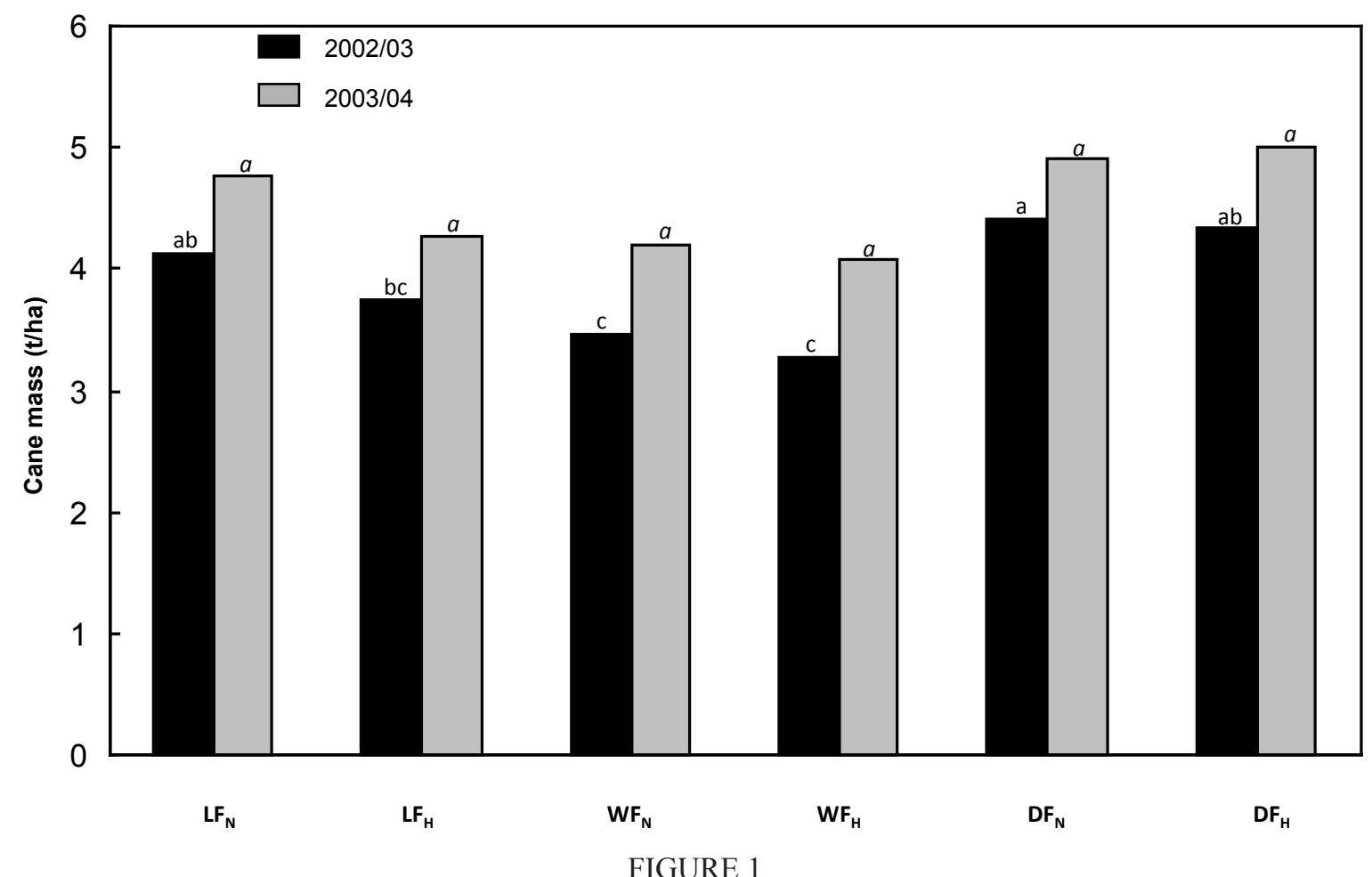

Effect of low frequency (LF), weekly (WF) and daily pulse fertigation (DF), as well as normal (N) and high (H) crop loads, on cane mass at pruning of Dan-ben-Hannah grapevines determined during two seasons near Paarl in the Berg River Valley region.

Data for each season were analysed separately. Columns designated by the same letter do not differ significantly ( $\mathrm{p} \leq 0.05)$. 
not affected by crop load (Fig. 1). Saayman and Lambrechts (1995a) nevertheless, observed, that by increasing the crop load of Barlinka by $93 \%$, i.e. from 15 to 29 bunches per grapevine, cane mass was reduced.

\section{Yield}

Berries from the $\mathrm{DF}_{\mathrm{N}}$ grapevines were bigger than those produced by the LF and WF grapevines, irrespective of their crop loads (Table 2). The berry mass of the $\mathrm{DF}_{\mathrm{H}}$ grapevines also tended to be higher than that produced by the $\mathrm{LF}_{\mathrm{H}}$ and $\mathrm{WF}_{\mathrm{H}}$ grapevines and similar in size to those produced by the $\mathrm{LF}_{\mathrm{N}}$ and $\mathrm{WF}_{\mathrm{N}}$ grapevines. The lower total diurnal leaf water potential experienced by the DF grapevines (Myburgh \& Howell, 2012) probably promoted bigger berries. Berry mass of Sultanina was also bigger when irrigation at 30\% plant available water (PAW) depletion throughout the season reduced water constraints compared to $60 \%$ or $90 \%$ depletion (Myburgh, 2003). Although PAW depletion level and irrigation cut-off had no effect on berry mass or volume of Sunred Seedless, the berry size of Muscat Supreme was more sensitive to drier soil conditions during the final stages of ripening, i.e. $>12^{\circ} \mathrm{B}$ (Myburgh \& Howell, 2007a). Crop load did not have any effect on berry mass (Table 2). Berries only tended to be smaller on the grapevines that bore a high crop load. Crop load also had no effect on Barlinka berry mass (Saayman \& Lambrechts, 1995b). However, berries were smaller where Carignane grapevines bore more clusters per grapevine (Kliewer et al., 1983). Berry volumes followed the same trends as berry mass (Table 2). There were no differences in berry density, i.e. berry mass divided by its volume, in the two seasons (data not shown). Mean berry density varied between $1.08 \mathrm{~g} / \mathrm{cm}^{3}$ and $1.09 \mathrm{~g} / \mathrm{cm}^{3}$. In 2002/03, bunches from the DF treatments were heavier compared to the $\mathrm{WF}_{\mathrm{H}}$ grapevines, and tended to be heavier than those of the LF treatments (Table 2). In 2003/04, bunches from the DF grapevines tended to be heavier than those of the other treatments. These trends were probably the result of differences in berry mass, which indicates the importance of the near-optimal grapevine water status experienced by the DF grapevines (Myburgh \& Howell, 2012). Barlinka bunch mass also tended to increase with an increase in soil water content (Fourie, 1989). Bunches from Dan-ben-Hannah grapevines with a high crop load tended to be smaller than their counterparts bearing a normal crop load. Similarly, the bunch mass of Barlinka grapevines bearing 29, 22 and 15 bunches per grapevine increased concomitantly (Saayman \& Lambrechts, 1995b).

In the 2002/03 season, the mean estimated yield for Danben-Hannah grapevines bearing the normal crop load was $22.9 \mathrm{t} / \mathrm{ha}$, whereas the grapevines bearing a high crop load produced $29.1 \mathrm{t} / \mathrm{ha}$. In the following season, the grapevines bearing a normal and a high crop load produced $24.7 \mathrm{t} / \mathrm{ha}$ and $31.8 \mathrm{t} / \mathrm{ha}$ respectively. As in the case of vegetative growth, increased irrigation volumes applied at longer intervals did not seem to have any negative effects on the mean yield of the LF and WF grapevines compared to lower volume irrigations

\section{TABLE 2}

Effect of low frequency (LF), weekly (WF) and daily pulse (DF) fertigation, as well as normal (N) and high (H) crop loads, on berry mass, volume, bunch mass, total soluble solids (TSS), total titratable acidity (TTA) and pH of Dan-ben-Hannah grapes determined at harvest during the 2002/03 and 2003/04 seasons near Paarl in the Berg River Valley region.

\begin{tabular}{|c|c|c|c|c|c|c|}
\hline \multirow[t]{3}{*}{ Season } & \multicolumn{6}{|c|}{ Fertigation-crop load treatment } \\
\hline & $\mathbf{L F} \mathbf{F}_{\mathrm{N}}^{(1)}$ & $\mathbf{L F}_{\mathbf{H}}$ & $\mathbf{W F}_{\mathrm{N}}$ & $\mathbf{W F}_{\mathbf{H}}$ & $\mathbf{D F}_{\mathrm{N}}$ & $\mathbf{D F}_{\mathrm{H}}$ \\
\hline & \multicolumn{6}{|c|}{ Berry mass (g) } \\
\hline $2002 / 03$ & $6.9 \mathrm{bc}^{(2)}$ & $6.8 \mathrm{bc}$ & $7.0 \mathrm{bc}$ & $6.7 \mathrm{c}$ & $7.7 \mathrm{a}$ & $7.3 \mathrm{ab}$ \\
\hline \multirow[t]{2}{*}{$2003 / 04$} & $7.5 \mathrm{~b}$ & $7.4 \mathrm{~b}$ & $7.6 \mathrm{~b}$ & $7.3 \mathrm{~b}$ & $8.1 \mathrm{a}$ & $7.8 \mathrm{ab}$ \\
\hline & \multicolumn{6}{|c|}{ Berry volume $\left(\mathrm{cm}^{3}\right)$} \\
\hline $2002 / 03$ & $6.4 \mathrm{bc}$ & $6.3 \mathrm{bc}$ & $6.4 \mathrm{bc}$ & $6.2 \mathrm{c}$ & $7.1 \mathrm{a}$ & $6.7 \mathrm{ab}$ \\
\hline \multirow[t]{2}{*}{$2003 / 04$} & $6.9 \mathrm{bc}$ & $6.8 \mathrm{bc}$ & $7.0 \mathrm{bc}$ & $6.7 \mathrm{c}$ & $7.5 \mathrm{a}$ & $7.2 \mathrm{ab}$ \\
\hline & \multicolumn{6}{|c|}{ Bunch mass (g) } \\
\hline $2002 / 03$ & $457 \mathrm{ab}$ & $435 \mathrm{ab}$ & $457 \mathrm{ab}$ & $379 \mathrm{~b}$ & $511 \mathrm{a}$ & 493 a \\
\hline $2003 / 04$ & $504 \mathrm{a}$ & $473 \mathrm{a}$ & $496 \mathrm{a}$ & $444 \mathrm{a}$ & $536 \mathrm{a}$ & $515 \mathrm{a}$ \\
\hline \multicolumn{7}{|c|}{ TSS $\left({ }^{\circ} \mathbf{B}\right)$} \\
\hline $2002 / 03$ & $16.1 \mathrm{ab}$ & $15.2 \mathrm{c}$ & $16.7 \mathrm{a}$ & $15.8 \mathrm{bc}$ & $16.3 \mathrm{ab}$ & $15.3 \mathrm{c}$ \\
\hline $2003 / 04$ & $16.6 \mathrm{ab}$ & $16.2 \mathrm{bc}$ & $16.9 \mathrm{a}$ & $16.4 \mathrm{bc}$ & $16.1 \mathrm{c}$ & $16.0 \mathrm{c}$ \\
\hline \multicolumn{7}{|c|}{ TTA (g/L) } \\
\hline $2002 / 03$ & $4.5 \mathrm{a}$ & $4.4 \mathrm{a}$ & $4.3 \mathrm{a}$ & $4.2 \mathrm{a}$ & $4.6 \mathrm{a}$ & $4.5 \mathrm{a}$ \\
\hline $2003 / 04$ & $5.5 \mathrm{a}$ & $5.3 \mathrm{a}$ & $5.4 \mathrm{a}$ & $5.3 \mathrm{a}$ & $5.8 \mathrm{a}$ & $5.7 \mathrm{a}$ \\
\hline \multicolumn{7}{|c|}{ pH } \\
\hline $2002 / 03$ & $3.77 \mathrm{a}$ & $3.76 \mathrm{a}$ & $3.77 \mathrm{a}$ & $3.77 \mathrm{a}$ & $3.75 \mathrm{a}$ & $3.72 \mathrm{a}$ \\
\hline $2003 / 04$ & $3.60 \mathrm{a}$ & $3.57 \mathrm{a}$ & $3.58 \mathrm{a}$ & $3.59 \mathrm{a}$ & $3.52 \mathrm{a}$ & $3.57 \mathrm{a}$ \\
\hline
\end{tabular}

(1) Refer to Table 1 for more details of the treatments.

(2) Values designated by the same letter within each row do not differ significantly $(\mathrm{p} \leq 0.05)$. 
applied at shorter intervals in the 2002/03 season (Myburgh \& Howell, 2012). It was previously reported that the yield of Waltham Cross table grapes depends strongly on the soil water regime, and that maximum yield is obtained when near field capacity soil conditions are maintained from bud break to véraison (Van Rooyen et al., 1980). Similarly, Barlinka grapevines irrigated at $15 \%$ PAW depletion level from bud break to véraison, followed by irrigation at 50\% PAW depletion to harvest, produced more grapes than grapevines irrigated at $85 \%$ PAW depletion either pre- or post-véraison (Fourie, 1989). Irrigation at 10\% PAW depletion increased Barlinka yield in comparison to irrigation at $60 \%$ PAW depletion (Myburgh, 1996). Sultanina grapevines growing in the Lower Orange River region also responded to PAW depletion levels in that yield increased with an increase in PAW (Myburgh, 2003).

\section{Sugar, acidity and pH}

In the 2002/03 season, the fertigation strategies had no effect on juice TSS in Dan-ben-Hannah grapes (Table 2). In 2003/04, the $\mathrm{DF}_{\mathrm{N}}$ grapevines produced less TSS than the $\mathrm{LF}_{\mathrm{N}}$ and $\mathrm{FW}_{\mathrm{N}}$ grapevines. Lower TSS in the DF grapevines compared to the $\mathrm{LF}_{\mathrm{N}}$ and $\mathrm{WF}_{\mathrm{N}}$ grapevines during 2003/04 was most probably related to lower water constraints (Myburgh \& Howell, 2012). However, this does not rule out the possibility that the bigger berries could have caused a dilution effect. Daily irrigations after véraison also negatively affected sugar accumulation in Barlinka berries (Fourie, 1989). In contrast, a wet soil regime (i.e. 15\% PAW depletion) during berry ripening had a positive impact on juice TSS in Waltham Cross grapes (Van Rooyen et al., 1980). Muscat of Alexandria table grapes that experienced severe post-véraison water deficits had higher TSS in comparison with a well watered control (El-Ansary et al., 2005). Myburgh (1996) reported no effects of PAW depletion level on TSS in Barlinka grapes at harvest. It was evident that increasing the crop load of Dan-ben-Hannah decreased TSS (Table 2). Similarly, Barlinka grapevines bearing a crop load of 15 bunches per grapevine produced higher juice TSS levels compared to ones bearing 29 bunches (Saayman \& Lambrechts, 1995b). However, increasing the crop load from 15 bunches to 22 bunches had no effect on juice TSS. There were no obvious trends in juice TTA and $\mathrm{pH}$ in Dan-ben-Hannah grapes with respect to fertigation strategy and crop load (Table 2). This was expected, since there were no pronounced differences in juice TTA and cation composition, particularly K (Howell \& Conradie, 2013). Similarly, increasing the crop load of Barlinka grapevines from 15 to 29 bunches per grapevine did not affect juice TTA (Saayman \& Lambrechts, 1995b).

\section{Grape quality}

Berry crack following rainfall was notably more pronounced in the case of the LF and WF grapevines, and eventually contributed to the low export percentages compared with the DF treatments (Table 3). Berry splitting or cracking can cause significant yield losses, and wet or humid atmospheric conditions are known to exacerbate the problem (Lang \& Thorpe, 1988). Furthermore, rainfall and humidity after véraison predispose grapes to splitting, Botrytis rot and other fungal diseases (Pérez-Harvey, 2008). The number of bunches with berry crack increased with the pressure at which the berry skins burst (Fig. 2). These differences are significant, since Dan-ben-Hannah berry skins are generally regarded as being strong compared to other cultivars such as Crimson Seedless (Hurndall, 2005). Therefore, these results suggest that the grapes of the DF grapevines had thinner or more elastic berry skins, which allowed them to adapt to rapid expansion when rainfall occurred. The ability of the berry skin to stretch at each development stage must be sufficient to accommodate the rapid expansion brought about by wet or humid atmospheric conditions so that splitting is avoided (Lang \& Thorpe, 1988). However, less berry crack does not rule out the possibility that larger bunches with larger berries could also have contributed to the higher number of export cartons from the DF treatments (Fig. 3). Export quality followed a similar trend in the 2003/04 season. Although berry crack also occurred in the 2003/04 season, damage to the grapes was not as extensive as in the $2002 / 03$ season. This

\section{TABLE 3}

Effect of low frequency (LF), weekly (WF) and daily pulse (DF) fertigation, as well as normal (N) and high (H) crop loads, on percentage export, local and reject quality of Dan-ben Hannah grapes determined at harvest during the 2002/03 and 2003/04 seasons near Paarl in the Berg River Valley region.

\begin{tabular}{|c|c|c|c|c|c|c|}
\hline \multirow[t]{3}{*}{ Season } & \multicolumn{6}{|c|}{ Fertigation-crop load treatment } \\
\hline & $\mathbf{L F}_{\mathrm{N}}{ }^{(1)}$ & $\mathbf{L F}_{\mathrm{H}}$ & $\mathbf{W F}_{\mathrm{N}}$ & $\mathbf{W F}_{\mathrm{H}}$ & $\mathrm{DF}_{\mathrm{N}}$ & $\mathrm{DF}_{\mathrm{H}}$ \\
\hline & \multicolumn{6}{|c|}{$\operatorname{Export}(\%)$} \\
\hline $2002 / 03$ & $59 \mathrm{bc}^{(2)}$ & $42 \mathrm{a}$ & $55 \mathrm{ab}$ & $41 \mathrm{a}$ & $74 \mathrm{c}$ & $65 \mathrm{bc}$ \\
\hline $2003 / 04$ & $59 \mathrm{ab}$ & $55 \mathrm{ab}$ & $59 \mathrm{ab}$ & $48 \mathrm{a}$ & $73 \mathrm{c}$ & $65 \mathrm{bc}$ \\
\hline \multicolumn{7}{|c|}{ Local (\%) } \\
\hline $2002 / 03$ & $20 \mathrm{a}$ & $26 \mathrm{a}$ & $23 \mathrm{a}$ & $26 \mathrm{a}$ & $18 \mathrm{a}$ & $19 \mathrm{a}$ \\
\hline 2003/04 & $24 \mathrm{a}$ & $25 \mathrm{a}$ & $24 \mathrm{a}$ & $27 \mathrm{a}$ & $18 \mathrm{a}$ & $21 \mathrm{a}$ \\
\hline \multicolumn{7}{|c|}{ Reject (\%) } \\
\hline $2002 / 03$ & $21 \mathrm{ab}$ & $32 \mathrm{~b}$ & $22 \mathrm{ab}$ & $32 \mathrm{~b}$ & $8 \mathrm{a}$ & $15 \mathrm{a}$ \\
\hline $2003 / 04$ & $18 \mathrm{abc}$ & $21 \mathrm{bc}$ & $17 \mathrm{abc}$ & $24 \mathrm{c}$ & $9 \mathrm{a}$ & $15 \mathrm{ab}$ \\
\hline
\end{tabular}

(1) Refer to Table 1 for more details of the treatments.

(2) Values designated by the same letter within each row do not differ significantly $(\mathrm{p} \leq 0.05)$. 
confirmed that the larger berries and bunches contributed to the higher export quality produced by DF grapevines in both seasons. The higher crop loads decreased the export percentage compared to normal crop load, irrespective of fertigation strategy. Furthermore, an increase in crop load increased the percentage of reject grapes for all treatments. An increase in crop load also induced smaller bunches with inferior colour, which reduced the export quality of Barlinka (Saayman \& Lambrechts, 1995b).

In the case of LF irrigation, the lower crop load reduced

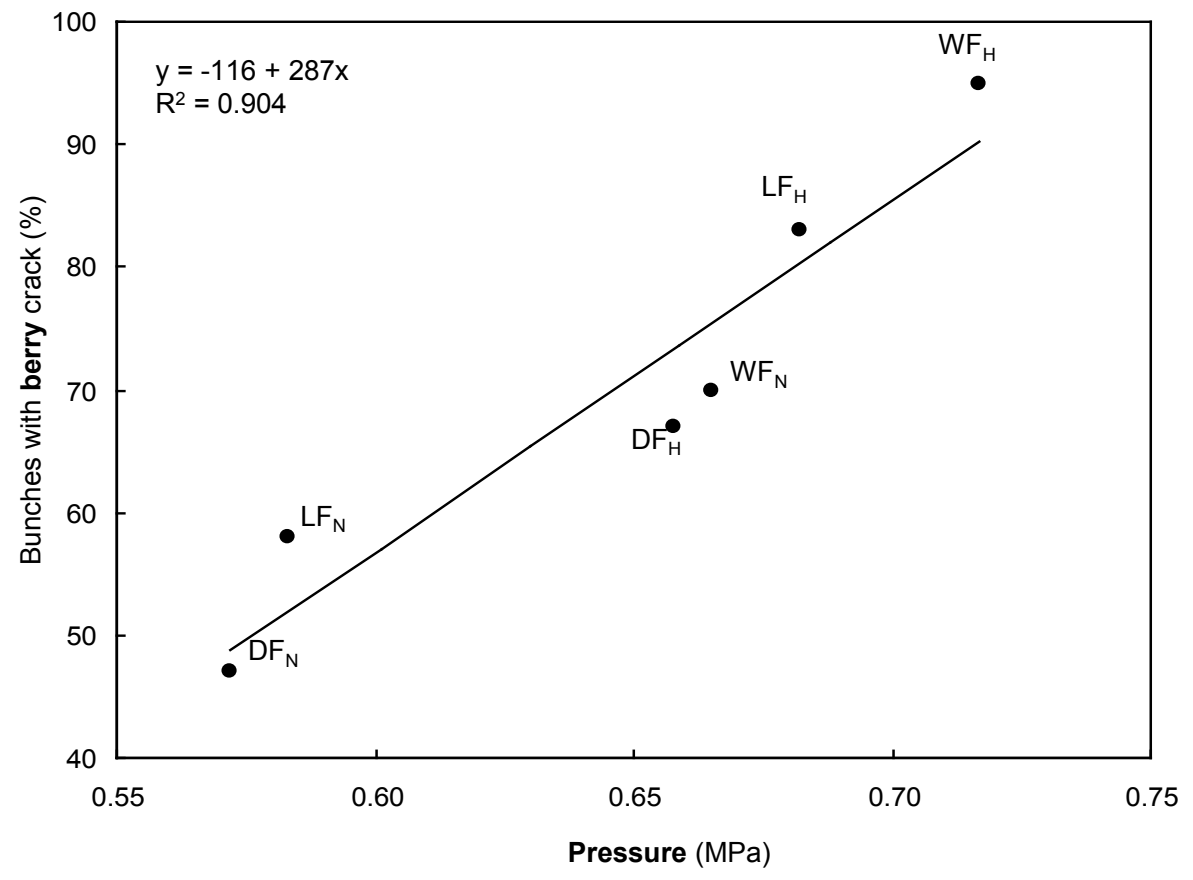

FIGURE 2

Relationship between percentage of Dan-ben-Hannah bunches with berry crack and the pressure at which berry skins burst determined in January 2003.

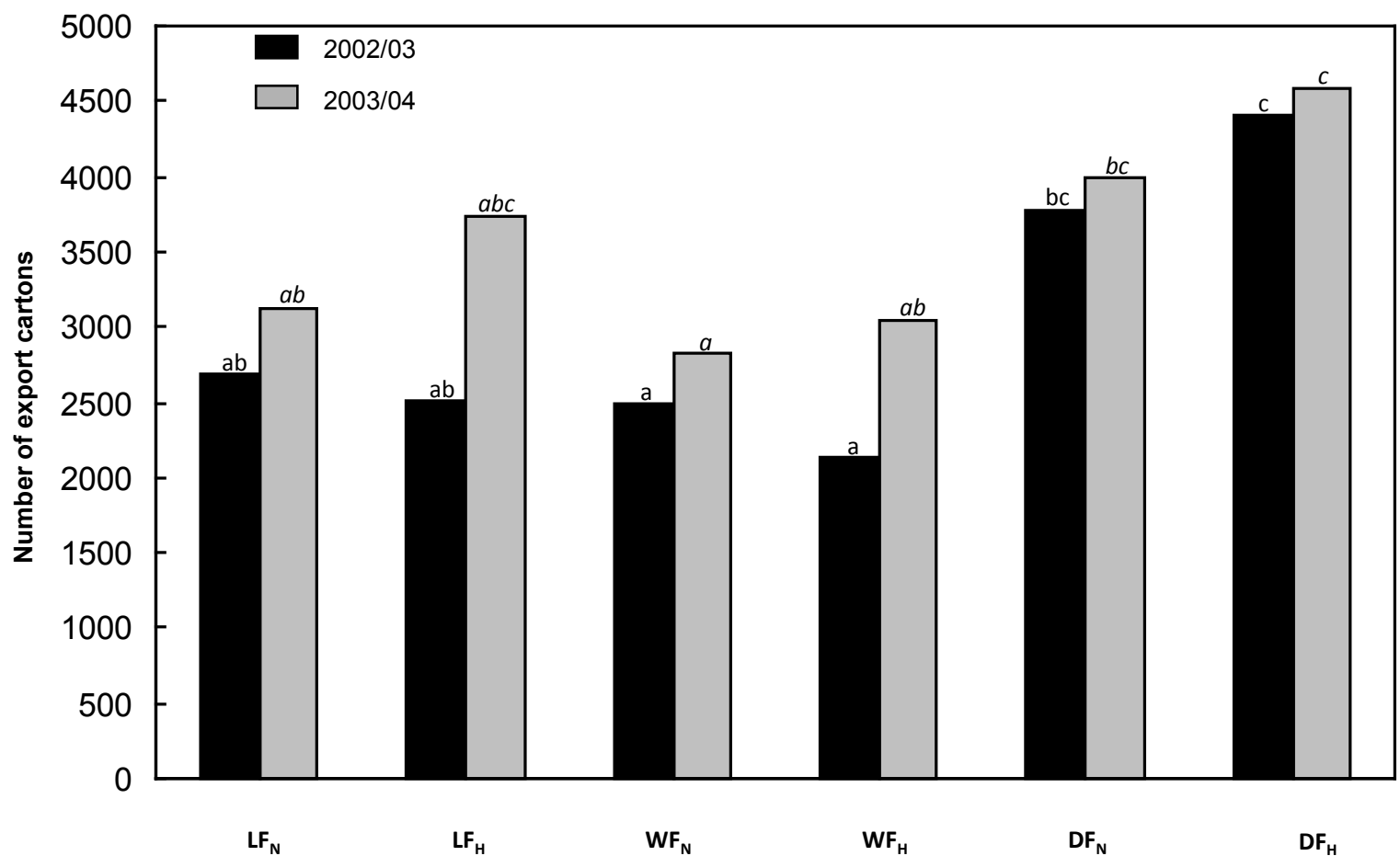

FIGURE 3

Effect of low frequency (LF), weekly (WF) and daily pulse fertigation (DF), as well as normal (N) and high (H) crop loads, on number of export cartons of Dan-ben-Hannah grapes determined during two seasons near Paarl in the Berg River Valley region. Data for each season were analysed separately. Columns designated by the same letter do not differ significantly ( $\mathrm{p} \leq 0.05$ ). 
the occurrence of loose berries during cold storage in the 2002/03 season (Table 4). However, the WF and DF treatments showed a contrary trend, for reasons that cannot be explained. The DF treatments, particularly the normal crop load, increased $\mathrm{SO}_{2}$ damage compared to the other fertigation frequencies. In the 2003/04 season, fertigation strategy and crop load did not affect loose berry incidence and $\mathrm{SO}_{2}$ damage. In both seasons, fertigation strategy and crop load did not affect Botrytis infection and the percentage of split berries (Table 4). A previous study also showed that PAW depletion level and irrigation cut-off did not affect the storage capability of Muscat Supreme (Myburgh \& Howell, 2007b). Similarly, daily irrigation by means of microsprinklers did not affect the grape storage capability of Barlinka compared to irrigation at longer intervals (Fourie, 1989).

During the 2002/03 season, the $\mathrm{DF}_{\mathrm{H}}$ grapevines produced grapes of inferior colour compared to the WF grapevines (Table 5). In 2003/04, differences in grape colour were more pronounced and the $\mathrm{DF}_{\mathrm{H}}$ grapevines produced grapes of poorer colour compared to the other treatments, with the exception of $\mathrm{LF}_{\mathrm{N}}$. Since the vegetative growth of the grapevines was comparable (Fig. 1), it is unlikely that less bunch exposure to sunlight could have contributed to the poorer colour. Poorer colouring was probably related to lower water constraints experienced by the DF grapevines (Myburgh \& Howell, 2012), resulting in larger berries (Table 2) in conjunction with a dilution effect due to the higher yield. The colour of Barlinka grapes irrigated at $10 \%$ PAW depletion showed a similar trend compared to higher depletion levels (Myburgh, 1996). Sunred Seedless also produced grapes poorer in colour when soil conditions were wetter from véraison to harvest (Myburgh \& Howell, 2007b). In addition, a negative affect of increasing crop load on the colour of Barlinka has been reported (Saayman \& Lambrechts, 1995b). The berry firmness of the $\mathrm{DF}_{\mathrm{H}}$ grapevines was also lower compared to their normal crop load counterparts. In the 2002/03 season, berry taste tended to be lowest for $\mathrm{DF}_{\mathrm{H}}$, while berry taste of the $\mathrm{DF}_{\mathrm{H}}$ grapes in 2003/04 was poorer compared to the $\mathrm{DF}_{\mathrm{N}}$ grapes. Poorer grape colour, firmness and taste resulted in lower overall grape quality in the 2003/04 season (Table 5). However, despite the poorer overall quality of the $\mathrm{DF}_{\mathrm{H}}$ grapes, they were still above the minimum standard for export. Generally, irrigation at $40 \%$ PAW depletion tended to improve Barlinka grape taste and colour and, although the berries were not the biggest, they were above the minimum standard for export (Myburgh, 1996). In contrast, a wet soil regime during ripening had a positive effect on the berry quality of Waltham Cross table grapes (Van Rooyen et al., 1980).

\section{CONCLUSIONS}

In general, different fertigation strategies did not affect vegetative growth, except in the first season, when WF resulted in poorer growth. Within a fertigation strategy, crop load had no affect on vegetative growth. Similarly, crop load had no effect on berry size and bunch mass. However, $\mathrm{DF}_{\mathrm{N}}$ resulted in bigger berries compared to the LF and WF treatments, but this did not necessarily reflect in bigger bunches. Crop load tended to reduce juice TSS, irrespective of fertigation strategy, particularly in the 2002/03 season. Neither fertigation strategy nor crop load had any effect on juice TTA and $\mathrm{pH}$. Less berry crack of the DF grapes contributed to higher yield, as well as the high export percentage obtained with this strategy. In conjunction with more healthy grapes being produced, bigger berries, and therefore better appearance, also contributed to the higher export quality of the DF grapes. Although the DF grapevines bearing a high crop load produced grapes of inferior colour and poorer overall impression, they were still within the norms for export. Therefore, under the conditions in this trial, higher crop loads of acceptable export quality

\section{TABLE 4}

Effect of low frequency (LF), weekly (WF) and daily pulse (DF) fertigation, as well as normal (N) and high (H) crop loads, on incidence of loose berries, $\mathrm{SO}_{2}$ damage, Botrytis infection and split berries of Dan-ben-Hannah grapes determined after cold storage during the 2002/03 and 2003/04 seasons near Paarl in the Berg River Valley region.

\begin{tabular}{|c|c|c|c|c|c|c|}
\hline \multirow{3}{*}{ Season } & \multicolumn{6}{|c|}{ Fertigation-crop load treatment } \\
\hline & $\mathbf{L F}_{\mathrm{N}}^{(1)}$ & $\mathbf{L F}_{\mathrm{H}}$ & $\mathbf{W F}_{\mathrm{N}}$ & $\mathbf{W F}_{\mathrm{H}}$ & $\mathbf{D F}_{\mathrm{N}}$ & $\mathbf{D F}_{\mathrm{H}}$ \\
\hline & \multicolumn{6}{|c|}{ Loose berries (\%) } \\
\hline $2002 / 03$ & $0.17 \mathrm{~b}^{(2)}$ & $0.57 \mathrm{a}$ & $0.54 \mathrm{a}$ & $0.31 \mathrm{ab}$ & $0.49 \mathrm{a}$ & $0.32 \mathrm{a}$ \\
\hline \multirow[t]{2}{*}{$2003 / 04$} & $0.51 \mathrm{a}$ & $0.35 \mathrm{a}$ & $0.20 \mathrm{a}$ & $0.20 \mathrm{a}$ & $0.28 \mathrm{a}$ & $0.25 \mathrm{a}$ \\
\hline & \multicolumn{6}{|c|}{$\mathrm{SO}_{2}$ damage $(\%)$} \\
\hline $2002 / 03$ & $0.98 \mathrm{bc}$ & $0.61 \mathrm{bc}$ & $1.15 \mathrm{ab}$ & $0.50 \mathrm{c}$ & $1.63 \mathrm{a}$ & $1.61 \mathrm{ab}$ \\
\hline \multirow[t]{2}{*}{$2003 / 04$} & $0.80 \mathrm{a}$ & $1.10 \mathrm{a}$ & $1.29 \mathrm{a}$ & $0.87 \mathrm{a}$ & $0.86 \mathrm{a}$ & $0.93 \mathrm{a}$ \\
\hline & \multicolumn{6}{|c|}{ Botrytis infection (\%) } \\
\hline $2002 / 03$ & $0.37 \mathrm{a}$ & $0.52 \mathrm{a}$ & $0.42 \mathrm{a}$ & $0.45 \mathrm{a}$ & $0.54 \mathrm{a}$ & $0.57 \mathrm{a}$ \\
\hline \multirow[t]{2}{*}{$2003 / 04$} & $1.15 \mathrm{a}$ & $1.08 \mathrm{a}$ & $1.50 \mathrm{a}$ & $1.23 \mathrm{a}$ & $1.09 \mathrm{a}$ & $0.73 \mathrm{a}$ \\
\hline & \multicolumn{6}{|c|}{ Split berries (\%) } \\
\hline $2002 / 03$ & $1.24 \mathrm{a}$ & $1.08 \mathrm{a}$ & $1.30 \mathrm{a}$ & $0.76 \mathrm{a}$ & $1.29 \mathrm{a}$ & $0.92 \mathrm{a}$ \\
\hline 2003/04 & $2.14 \mathrm{a}$ & $2.67 \mathrm{a}$ & $2.95 \mathrm{a}$ & $2.60 \mathrm{a}$ & $3.31 \mathrm{a}$ & $3.35 \mathrm{a}$ \\
\hline
\end{tabular}

(1) Refer to Table 1 for more details of the treatments.

(2) Values designated by the same letter within each row do not differ significantly $(\mathrm{p} \leq 0.05)$. 
TABLE 5

Effect of low frequency (LF), weekly (WF) and daily pulse (DF) fertigation, as well as normal (N) and high (H) crop loads, on colour, firmness, taste and overall impression after cold storage of Dan-ben-Hannah grapes determined during the 2002/03 and 2003/04 seasons near Paarl in the Berg River Valley region.

\begin{tabular}{|c|c|c|c|c|c|c|}
\hline \multirow{3}{*}{ Season } & \multicolumn{6}{|c|}{ Fertigation-crop load treatment } \\
\hline & $\mathbf{L F}_{\mathrm{N}}^{(1)}$ & $\mathbf{L F}_{\mathbf{H}}$ & $\mathbf{W F}_{\mathrm{N}}$ & $\mathbf{W F}_{\mathrm{H}}$ & $\mathbf{D F}_{\mathrm{N}}$ & $\mathrm{DF}_{\mathrm{H}}$ \\
\hline & \multicolumn{6}{|c|}{ Colour $^{(3)}$} \\
\hline $2002 / 03$ & $-0.4 a b^{(2)}$ & $0.3 \mathrm{ab}$ & $0.6 \mathrm{a}$ & $0.6 \mathrm{a}$ & $0.2 \mathrm{ab}$ & $-1.2 b$ \\
\hline $2003 / 04$ & $-0.2 \mathrm{ab}$ & $0.2 \mathrm{a}$ & $0.3 \mathrm{a}$ & $0.4 \mathrm{a}$ & $0.3 \mathrm{a}$ & $-1.0 \mathrm{~b}$ \\
\hline \multicolumn{7}{|c|}{ Firmness $^{(3)}$} \\
\hline $2002 / 03$ & $-0.2 \mathrm{ab}$ & $0.2 \mathrm{ab}$ & $-0.2 a b$ & $0.2 \mathrm{ab}$ & $0.6 \mathrm{a}$ & $-0.5 b$ \\
\hline 2003/04 & $-0.1 \mathrm{ab}$ & $0.0 \mathrm{ab}$ & $0.1 \mathrm{ab}$ & $0.0 \mathrm{ab}$ & $0.5 \mathrm{a}$ & $-0.4 \mathrm{~b}$ \\
\hline \multicolumn{7}{|c|}{ Taste $^{(3)}$} \\
\hline $2002 / 03$ & $-0.1 \mathrm{a}$ & $0.1 \mathrm{a}$ & $0.1 \mathrm{a}$ & $0.3 \mathrm{a}$ & $0.1 \mathrm{a}$ & $-0.5 \mathrm{a}$ \\
\hline 2003/04 & $0.0 \mathrm{a}$ & $0.1 \mathrm{a}$ & $0.2 \mathrm{a}$ & $0.2 \mathrm{a}$ & $0.1 \mathrm{a}$ & $-0.6 \mathrm{~b}$ \\
\hline \multicolumn{7}{|c|}{ Overall impression $^{(3)}$} \\
\hline $2002 / 03$ & $0.1 \mathrm{a}$ & $0.1 \mathrm{a}$ & $0.2 \mathrm{a}$ & $0.0 \mathrm{a}$ & $0.5 \mathrm{a}$ & $-0.8 \mathrm{a}$ \\
\hline $2003 / 04$ & $0.0 \mathrm{ab}$ & $-0.1 \mathrm{ab}$ & $0.3 \mathrm{a}$ & $0.1 \mathrm{a}$ & $0.4 \mathrm{a}$ & $-0.7 b$ \\
\hline
\end{tabular}

(1) Refer to Table 1 for more details of the treatments.

(2) Values designated by the same letter within each row do not differ significantly $(\mathrm{p} \leq 0.05)$.

${ }^{(3)}$ Values are maximum likelihood estimators (Xbetas).

grapes could be sustained by DF grapevines. Considering the results of this study, the daily pulse fertigation strategy should not be regarded as the ultimate solution for table grape production under South African conditions. However, it can be recommended for vineyards on poor soils, e.g. with low water holding and cation exchange capacities, or for cultivars in which berry crack is a common problem.

\section{LITERATURE CITED}

Conradie, W.J., 1980. Seasonal uptake of nutrients by Chenin blanc in sand culture: I. Nitrogen. S. Afr. J. Enol. Vitic. 1, 59-65.

Conradie, W.J., 1981. Seasonal uptake of nutrients by Chenin blanc in sand culture: II. Phosphorus, potassium, calcium and magnesium. S. Afr. J. Enol. Vitic. 2, 7-13.

Conradie, W.J. \& Myburgh, P.A., 2000. Fertigation of Vitis vinifera L. cv. Bukettraube/110 Richter on a sandy soil. S. Afr. J. Enol. Vitic. 21, 40-48.

El-Ansary, D.O., Nakayama, S., Hirano, K. \& Okamoto, G., 2005. Response of Muscat Alexandria table grapes to post-veraison regulated deficit irrigation in Japan. Vitis 35, 45-46.

Fourie, A., 1989. The effect of four soil water regimes on the performance of Barlinka table grapes in the Hex River Valley. Thesis, Stellenbosch University, Private Bag X1, 7602 Matieland, South Africa.

Howell, C.L. \& Conradie, W.J., 2013. Comparison of three different fertigation strategies for drip irrigated table grapes - Part II. Soil and grapevine nutrient status. S. Afr. J. Enol. Vitic. 34, 10-20.

Hurndall, R., 2005. A guide to deciduous fruit of South Africa. Deciduous Fruit Producers' Trust. P.O. Box 163, 7622, Paarl, South Africa.

Keller, M., 2005. Deficit irrigation and vine mineral nutrition. Am. J. Enol. Vitic. 56, 267-283.

Kliewer, M., Freeman, B.M. \& Hossom, C., 1983. Effect of irrigation, crop level and potassium fertilization on Carignane vines. I. Degree of water stress and effect on growth and yield. Am. J. Enol. Vitic. 34, 186-196.
Lang, A. \& Thorpe, M., 1988. Why do grape berries split? Proc. 2nd Intern. Cool Climate Vit. and Oen. Symp., January 1998, Auckland, New Zealand. pp. $69-71$.

Le Roux, E.G., 1974. A climate classification for the South Western Cape viticultural areas (in Afrikaans). Thesis, Stellenbosch University, Private Bag X1, 7602 Matieland, South Africa.

McCullagh, P. \& Nelder, J.A., 1989 ( $2^{\text {nd }}$ ed). Generalized linear models. Chapman Hall, New York.

Myburgh, P.A., 1996. Response of Vitis vinifera L. cv. Barlinka/Ramsey to soil water depletion levels with particular reference to trunk growth parameters. S. Afr. J. Enol. Vitic. 17, 3-14.

Myburgh, P.A., 2003. Responses of Vitis vinifera L. cv. Sultanina to level of soil water depletion under semi-arid conditions. S. Afr. J. Enol. Vitic. $24,16-24$

Myburgh, P.A., 2010. Practical guidelines for the measurement of water potential in grapevine leaves. Wynboer Technical Yearbook, 11-13.

Myburgh, P.A., 2012. Comparing irrigation systems and strategies for table grapes in the weathered granite-gneiss soils of the Lower Orange River valley. S. Afr. J. Enol. Vitic. 33, 184-197.

Myburgh, P.A. \& Howell, C.L., 2007a. Responses of Sunred Seedless and Muscat Supreme to irrigation during berry ripening. I - Growth, yield and juice analyses. SA Fruit Journal Dec 06/Jan 07, 48-53.

Myburgh, P.A. \& Howell, C.L., 2007b. Responses of Sunred Seedless and Muscat Supreme to irrigation during berry ripening. II - Quality aspects. SA Fruit Journal Feb 07/March 07, 28-32.

Myburgh, P.A. \& Howell, C.L., 2012. Comparison of three different fertigation strategies for drip irrigated table grapes - Part I. Soil water status, root system characteristics and plant water status. S. Afr. J. Enol. Vitic. 33, 264-274.

Pérez-Harvey, J., 2008. Nutrition and irrigation related problems in table grapes. Acta Hort. 785, 175-182. 
Reynolds, A.G., Lowrey, W.D. \& De Savigny, C., 2005. Influence of irrigation and fertigation on fruit composition, vine performance, and water relations of Concord and Niagara grapevines. Am. J. Enol. Vitic. 56, 110 128.

Saayman, D. \& Lambrechts, J.J.N., 1995a. The effect of irrigation system and crop load on the vigour of Barlinka table grapes on a sandy soil, Hex River Valley. S. Afr. J. Enol. Vitic. 16, 27-34.

Saayman, D. \& Lambrechts, J.J.N., 1995b. The effect of fertilisation on the performance of Barlinka table grapes on sandy soil, Hex River Valley. S. Afr. J. Enol. Vitic. 16, 41-49.
SAS, 1999. SAS/STAT User's Guide, Version 8, 1st printing, Volume 2. SAS Institute Inc, SAS Campus Drive, Cary, North Carolina 27513.

Shapiro, S.S. \& Wilk, M.B., 1965. An analysis of variance test for normality (complete samples). Biometrika 52, 591-611.

Van Rooyen, F.C., Weber, H.W. \& Levin, I., 1980. The response of grapes to a manipulation of the soil-plant-atmosphere continuum. I. Growth, yield and quality responses. Agrochemophysica 12, 59-68.

Winkler, A.J., 1962. General viticulture. University of California Press, Los Angeles. 